\title{
Přehledové studie: jejich typologie, funkce a způsob vytváření
}

\author{
Jiří Mareš
}

\author{
Univerzita Karlova v Praze, Lékařská fakulta v Hradci Králové
}

Redakci zasláno 9. 5. 2013 / upravená verze obdržena 4. 9. 2013 / k uveřejnění přijato 6. 9. 2013

\begin{abstract}
Abstrakt: Studie seznamuje čtenáře s tím, jak napsat kvalitní přehledovou studii, která by shrnula soudobé poznatky o zvoleném výzkumném tématu. Cílem studie je předložit typologii přehledových studií; charakterizovat různé funkce, jež mohou jednotlivé typy přehledových studií plnit; ukázat, jak se má postupovat při výběru témat, při přípravě podkladů a při vlastním sepisování přehledové studie. V první části je představeno 11 typů přehledových studií, jak těch obecně známých, tak i méně známých. Ve druhé části je podán stručný přehled žánrů, které nepatří do kategorie přehledových studií. Třetí část charakterizuje rozdílné funkce, které přehledové studie plní (usnadňují porozumění předkládanému výzkumu, jsou přínosem pro autora studie, pro vývoj oboru, pro ostatní badatele). Čtvrtá část textu přibližuje problémy, před nimi stojí autor při volbě tématu pro přehledovou studii a nabízí možná řešení. Pátá část shrnuje postup při přípravě podkladů pro přehledovou studii (rešerše literatury, zúžení prvotního výběru prací, kritické čtení, analýza textů, tvorba přehledových tabulek). Šestá část nabízí rady, jak postupovat při samotném sepisování přehledové studie. Tam, kde je to účelné, jsou vedle doporučení, jak správně postupovat, zmiňovány i typické chyby, jichž by se měl autor vyvarovat. Ve vyspělých zemích mají zájemci k dispozici tři typy materiálů, které učí studenty a mladé vědecké pracovníky, jak mají psát přehledové studie. Jsou to doporučení, která lze nalézt na webových stránkách univerzit (obvykle v rámci tzv. Writing Centres), jsou k dispozici časopisecké články na toto téma anebo vycházejí obsáhlejší příručky. V České republice zatím takový soubor doporučení nebyl k dispozici. Předkládaný přehled se snaží tuto mezeru zaplnit. Kromě obecných rad a doporučení je přehled doplněn konkrétními ukázkami.
\end{abstract}

Klíčová slova: přehledová studie, literární přehled, kritický přehled, psaní, doporučení

Vědecko-výzkumná činnost na kterékoli úrovni (počínaje pregraduálními kvalifikačními pracemi studentů, přes doktorské disertace až po vědeckou práci na vysokých školách a ve specializovaných výzkumných ústavech) se na počátku výzkumu neobejde bez důkladného zmapování toho, co bylo zatím 
v dané výzkumné oblasti vykonáno. Pro tyto účely vznikl v odborné literatuře specifický žánr, který se označuje názvem přehledová studie.

Důležitost tohoto typu prací je nesporná, ale v České republice (na rozdíl od vyspělých zemí) nebývají ani studenti, ani mladí adepti vědy hlouběji seznamováni s pravidly pro vytváření přehledových studií, ani neprobíhá praktický nácvik psaní přehledůํ. Lze to doložit např. obsahem př́ruček pro psaní diplomových prací, at' už domácích (Spousta, 2000) či přeložených (např. Eco, 1997), anebo obsahem př́ruček pro psaní disertačních a vědeckých prací (např. Geršlová, 2009).

V zahraničí se setkáváme se třemi typy materiálů, které učí studenty a mladé vědecké pracovníky, jak mají psát přehledové studie. Jsou to doporučení, která lze nalézt na webových stránkách univerzit (viz např. Mongan-Rallis, 2006; Mayer, 2009; Writing Academic Review - Trent University, 2010 aj.), jsou k dispozici speciální časopisecké články (např. Bem, 1995; Randolph, 2009) anebo rozsáhlejší prŕíručky (např. Hart, 2005; Galvan, 2006; Ridley, 2012).

Protože se touto problematickou dlouhodobě zabýváme jak pedagogicky (při výuce doktorandů-lékařů ${ }^{2}$ ), tak i prakticky (psaním přehledových studií do různých časopisů), připravili jsme studii o tom, jak správně psát přehledové studie. Je primárně určena doktorandům a začínajícím vědeckým pracovníkům. Doufáme však, že i zkušení vědečtí pracovníci v ní najdou dílčí náměty, jak obohatit tvorbu svých přehledových prací.

Cíle předkládané práce jsou: (1) podrobněji charakterizovat nejběžnější typy přehledových studií; (2) s oporou o odbornou literaturu shrnout a utřídit základní funkce, které přehledové studie věnované empirickým výzkumům mohou plnit; (3) ukázat, jak postupovat při výběru témat pro přehledovou studii; (4) nabídnout vhodné postupy, jež usnadňují př́ípravu podkladů pro přehledovou studii; (5) upozornit na chyby, jichž se začínající autoři při tvorbě přehledových studií obvykle dopouštějí; (6) shrnout základní doporučení, jimiž se může autor řídit při samotném sepisování přehledové studie.

1 Na zahraničních univerzitách existují samostatná pracoviště (zpravidla označovaná jako Writing centres), která pro studenty pořádají speciální kursy.

2 Viz napřs. předmět nazvaný Příprava odborné přednášky a odborné publikace (Mareš, 1995). 


\section{Typy přehledových studií}

$\mathrm{V}$ nadpise je použito množné číslo, které naznačuje, že typů přehledových studií může být více než jeden. Podrobnější výklad konkrétních typů je uveden níže. Zde pouze připomeneme, že existují v zásadě dva typy přehledových studií.

První, běžnější typ bývá součástí originální výzkumné studie, tedy studie, která referuje o jednom výzkumu. Text vytváří nezbytné předpolí pro další výklad; zasazuje předkládaný výzkum do širšího badatelského kontextu. V kvalifikačních pracích (bakalářských, magisterských, doktorských) mívá přehled dosavadních výzkumů na dané téma rozsah desítek stran. V časopiseckých výzkumných článcích figuruje v jejich úvodní části a mívá rozsah od jedné do dvou až tř́ tištěných stran textu.

Druhý, specifičtější typ má podobu samostatné, ucelené přehledové studie, která mapuje výzkum ve zvolené oblasti. Věnuje_se jen souhrnnému pohledu na stav bádání v dané oblasti: vybírá, analyzuje, hodnotí a syntetizuje výsledky mnoha desítek výzkumných prací na dané téma.

V odborné literatuře se můžeme setkat s řadou odlišných typů přehledových studií. Jejich označení, obsahové zaměření i uváděné počty jsou u jednotlivých autorů rozdílné. Např. Mayer (2009) uvádí 7 typů, Grantová a Booth (2009) dokonce 14. Přehledové studie se také liší svým tematickým zaměřením: existují přehledové studie, které shrnují dosavadní empirické výzkumy v dané oblasti, a dále přehledové studie, které analyzují a shrnují teoretické přístupy v dané oblasti (dosavadní teorie, používané koncepty, silné i slabé stránky dosavadních teoretických přístupů a vývojové trendy). V této práci se budeme věnovat pouze prvnímu typu, tj. studiím, jež shrnují empirické výzkumy.

Navíc musíme upozornit na věcnou stránku přehledových studií. Jejich autoři berou téměř za samozřejmou věc, že se do jednotlivých typů přehledů zařazují pouze výzkumné studie, které jsou napsány v tom jazyce, který autor přehledu ovládá; zpravidla jde o angličtinu. Výzkumy publikované v jiném jazyce než je angličtina, se do takových přehledů dostávají spíše výjimečně (obvykle jen v př́padech, kdy se jedná o multikulturní tematiku). S volbou jazyka ovšem úzce souvisí skutečnost, že získané výsledky bývají determinovány sociokulturními zvláštnostmi dané země (např. zvláštnostmi rodinné výchovy, školským a zdravotnickým systémem, kulturními zvyklostmi, indi- 
vidualistickou či kolektivistickou orientací společnosti atd.). Proto je třeba se zobecněními, která vyplývají z různých typů přehledů, pracovat velmi obezřetně, tj. neaplikovat je mechanicky v odlišných sociokulturních podmínkách.

V některých domácích přehledových studiích se můžeme setkat s rozdělením textu do dvou samostatných oddílů: jeden shrnuje výzkumy v České republice (příp. k nim ještě přiřazuje výzkumy na Slovensku), druhý oddíl pak shrnuje zahraniční výzkumy. Vhodnější - podle našeho názoru - je postup, který bere výzkumy na dané téma (a provedené v obdobných sociokulturních podmínkách) jako celek. V oddíle Diskuse však autor přehledu mủže analyzovat, v čem se výsledky u nás a ve světě shodují, v čem se liší, př́íp. které aspekty se u nás nezkoumají a zkoumat by se měly.

Tolik vstupní upozornění a nyní je čas podívat se podrobněji na různé typy přehledových studií. Vybrali jsme všechny hlavní typy přehledových studií, které se objevují v odborné literatuře. Uspořádali jsme je podle stoupající náročnosti na jejich př́pravu a okomentujeme je $\mathrm{s}$ oporou o dostupnou literaturu (např. Grant \& Booth, 2009; Khangura et al., 2012; Sipe \& Curlette, 1997).

Literární přehled (literature review): obecné, zastřešující označení pro různé typy přehledů literárních zdrojů. Ve výzkumném kontextu se jím rozumí přehled dosavadních poznatků o zvoleném tématu za určité časové období. Přehled se opírá o vyhledané výzkumné studie na dané téma, o analýzu a zobecnění jejich výsledků.

Tradiční/narativní přehled (traditional/narrative review): shrnující přehled, který se opírá o rozsáhlejší soubor prací na dané téma za zvolené časové období. Autor při tvorbě přehledu vychází z pečlivě volených výzkumných otázek či stanovených hledisek. Popisuje poznatky získané dosavadními výzkumy, sumarizuje je, identifikuje rozpory v názorech autorů i ve výsledcích, které uvádějí. Dospívá k obecnějším závěrům a doporučením. Studie mívá podobu výkladu různých aspektů problému. Kvalita přehledu závisí mj. na výběru pramenů, z nichž autor čerpá, na způsobu rozboru, na odborné erudici autora a jeho zkušenostech s tímto typem studií.

Mapující přehled / systematické mapování (mapping review / systematic map): studie, která se opírá o rozsáhlejší soubor prací na dané téma za zvolené časové období. Autor analyzuje jednotlivé výzkumné studie, třídí je, shlukuje do větších celků. Někdy graficky znázorňuje zkoumaná témata a vztahy mezi nimi, vztahy mezi výzkumnými centry např. pomocí pojmových map. Závěry pak slouží jako podklad pro jiné přehledy anebo pro orientaci dalšího výzkumu $\mathrm{v}$ dané oblasti.

Systematický přehled (systematic review): studie, která se opírá o pokud možno úplný, tedy vyčerpávající soubor prací na dané téma za zvolené časové období. Autor velmi důkladně analyzuje kvantitativně zaměřené výzkumné studie publikované i nepublikované (např výzkumné zprávy) a svůj postup detailně popisuje. Jednotlivé výzkumné studie hodnotí z různých hledisek 
a výsledky hodnocení obvykle prezentuje v podobě přehledových tabulek. Závěry, k nimž dospívá, formuluje v podobě zobecnění. Upozorňuje na neřešené aspekty daného tématu, na rozpory v empirických nálezech i na metodologické problémy dosavadních výzkumů. Zkušenosti z medicíny bilancuje např. Moher et al. (2007).

Kritický přehled (critical review): jde o shrnující přehled, který se opírá o rozsáhlejší soubor prací na dané téma za zvolené časové období. Autor při tvorbě přehledu jde nad popis zjištěných poznatků. Důkladně analyzuje zvolené teoretické př́stupy, použité koncepty, metodologické přístupy a kriticky hodnotí jejich kvalitu, specifikuje jejich silné i slabé stránky. Sleduje proměny zvoleného výzkumného tématu $\mathrm{v}$ čase, posuny $\mathrm{v}$ koncepčních přístupech, upozorňuje na problematická místa. Závěry studie mají charakter kritické bilance dosavadního stavu a obsahují návrh nového modelu nebo návrh nových výzkumných hypotéz.

Integrativní přehled (integrative review): studie, která sumarizuje dosavadní poznatky řady výzkumných studií (experimentálních i neexperimentálních), ale i teoretických prací na dané téma za zvolené časové období. Umožňuje vhled a hlubší porozumění určitému procesu, vědeckému či aplikačnímu problému. Studie diskutuje používané pojmy, existující teorie, metodologické přístupy a vyústuje v konkrétní doporučení založená na důkazech (evidencebased). Doporučení mívají podobu souhrnné tabulky nebo vývojového diagramu. Blíže viz Whittemore \& Knafl (2005).

Rychlý přehled (rapid review): studie, která má rámcově odpovědět na jeden praktický problém nebo pomoci decizním orgánům při koncepčním rozhodnutí, které spěchá. Autor dostane zadání, definuje si kritéria, podle nichž provede literární rešerši (bud' klíčových nebo novějších publikací). Zvolí strategii hodnocení, popíše data uváděná ve vybraných výzkumných studiích, utřídí je a zformuluje odpověd’ na zadanou otázku. Na rozdíl od systematických studií, které se zpracovávají v průměru dva roky, mívá na zpracování rychlého přehledu obvykle jeden měsíc. Interpretace nálezů je tedy vázána na použité zdroje, zobecnění závěrů je limitováno (viz Khangura et al., 2012).

Meta-analýza (meta-analysis): studie aplikující statistické postupy s cílem shrnout výsledky řady kvantitativně zaměřených výzkumných studií, které se zabývají stejným nebo podobným problémem. Zjištujue velikost účinku zkoumaných proměnných. Meta-analýza kvantitativně odpovídá na otázku, zda existují nějaké prokazatelné konfigurace a seskupení výsledků $\mathrm{v}$ celém souboru zkoumaných studií, a to v závislosti na různých podmínkách, na zkoumaných subpopulacích, použitých metodách atd. (podrobnosti viz Hendl, 2004, s. 491 a násl.).

Meta-syntéza (meta-synthesis): shrnující přehled, který se opírá o rozsáhlejší soubor metaanalýz na dané téma za zvolené časové období. Podle stanovených kritérií jsou vybrány vhodné meta-analýzy, které zobecňují poznatky o daném tématu. Každá meta-analýza se v rámci vyššího celku (tj. meta-syntézy) stává sama jednotkou vyšší analýzy. Výsledkem jsou obecnější poznatky o daném tématu, napřs prediktory určitého vyústění sledovaných procesů, klíčové proměnné daného tématu a velikost jejich efektu (viz Sipe \& Curlette, 1997).

Kvalitativní systematický přehled (qualitative systematic review / qualitative evidence synthesis): shrnující přehled, který se opírá o rozsáhlejší soubor kvalitativních výzkumů na dané téma za zvolené časové období. Autor analyzuje jednotlivé kvalitativně zaměřené studie, sleduje, která témata či konstrukty badatelé identifikovali, ke kterým teoriím či modelům nakonec dospěli. 


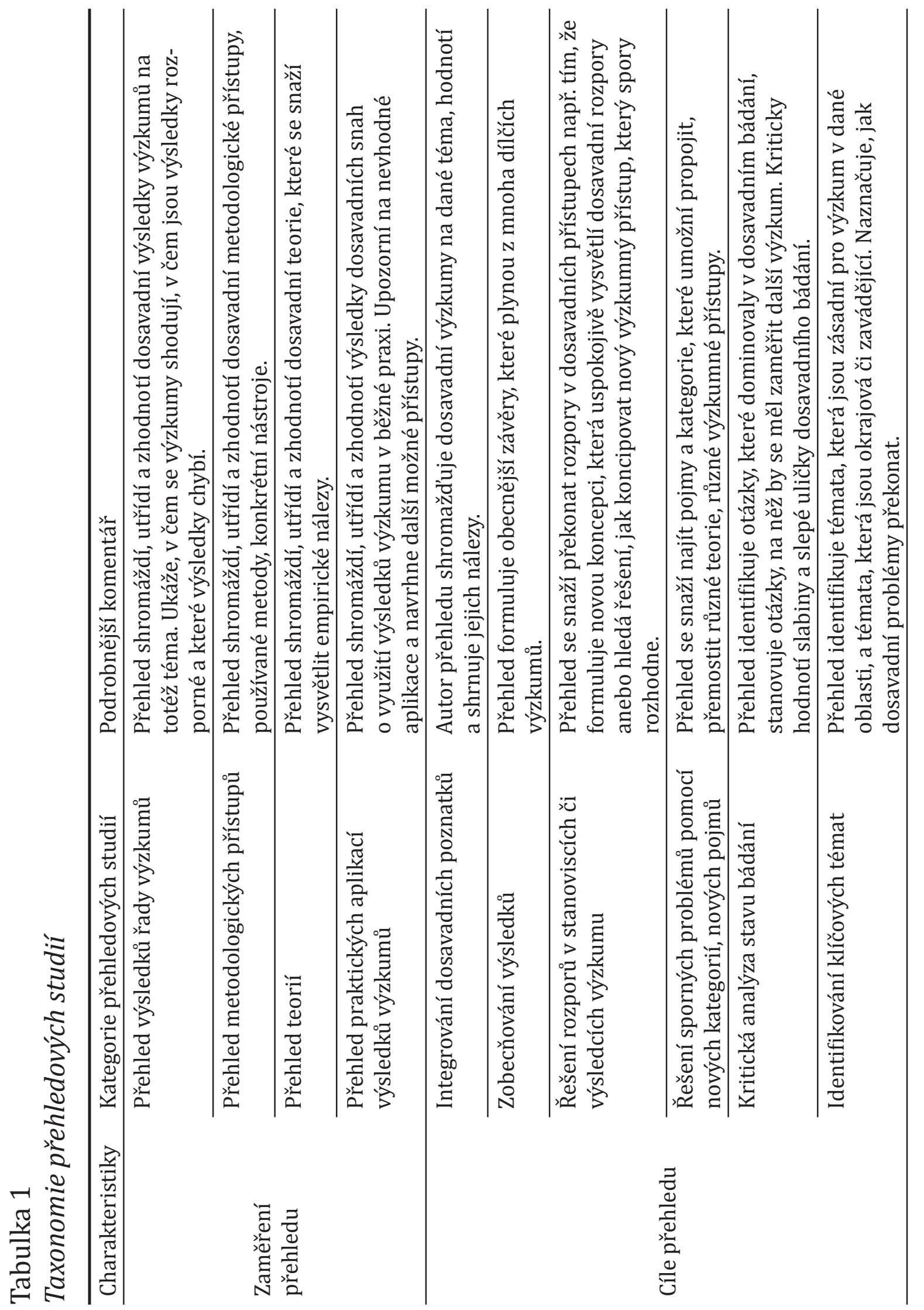




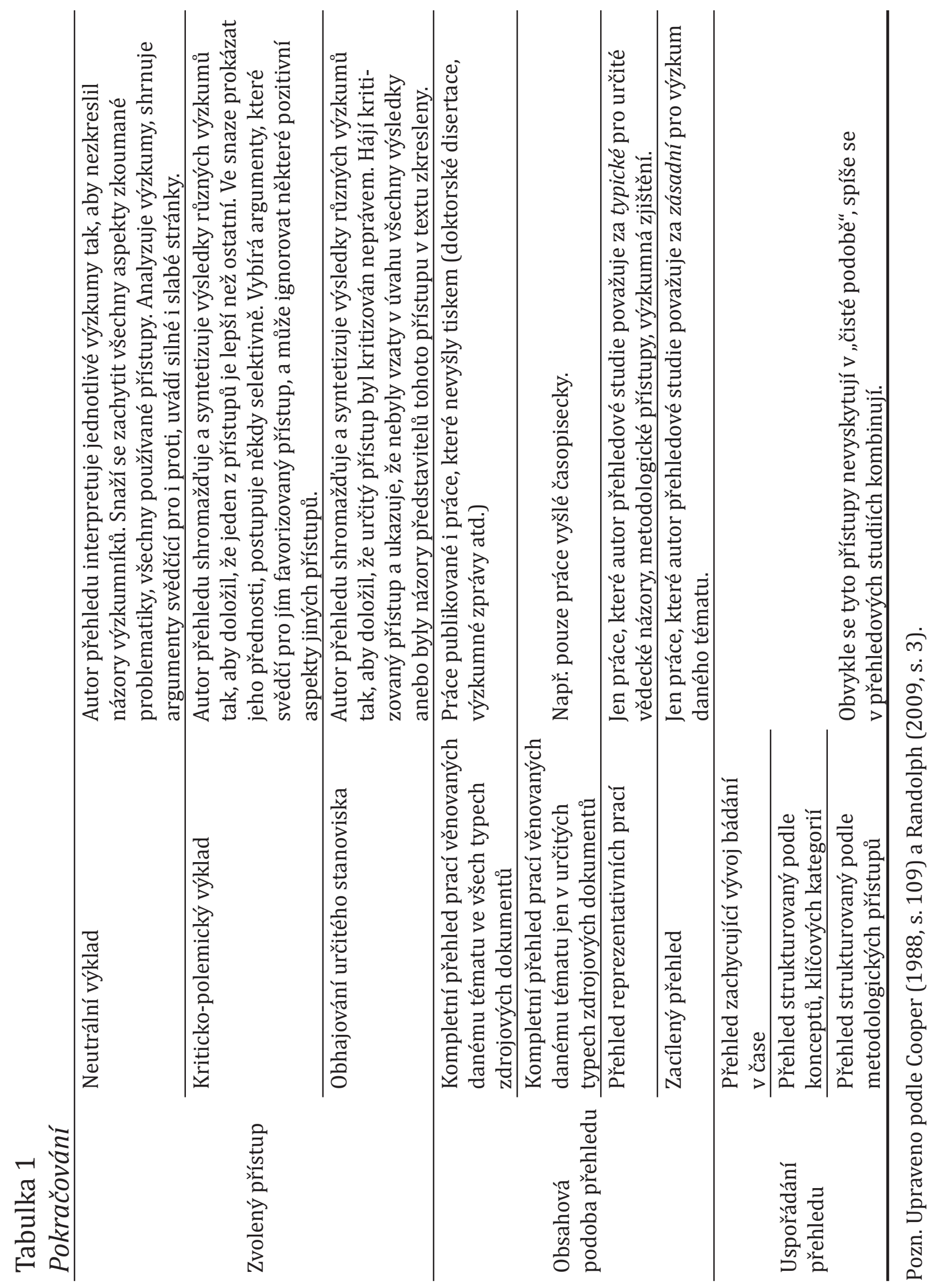


Přehled smíšených studií (mixed studies review / mixed methods review): shrnující přehled, který se opírá o rozsáhlejší soubor smíšených výzkumů na dané téma za zvolené časové období. Autor analyzuje jednotlivé výzkumné studie; sleduje, které kvantitativní a kvalitativní metody byly použity, jaký byl jejich vzájemný vztah a k jakým závěrům výzkumy dospěly.

Zatím jsme uváděli jednotlivé typy přehledových studií samostatně. Můžeme se však na ně podívat jako na celek a seskupit je podle pěti hledisek do pěti skupin: zaměření přehledu, cíle přehledu, zvolený přístup, obsah přehledu, uspořádání přehledu (viz tab. 1 na s. 432-433).

Tato část naší práce shrnula různé typy studií, které patří do žánru přehledových studií. Zbývá ještě doplnit negativní vymezení.

\section{2 Žánry, které nepatří do přehledových studií}

Nadpis tohoto oddílu lze zjednodušit do výroku: co přehledovou studií není. Především původní výzkumná studie, která referuje o jednom jediném konkrétním výzkumu, o jeho cílech, zkoumaném souboru, použitých metodách, hlavních výsledcích. Studie, která diskutuje konkrétní empirické nálezy a ústí v závěry, jež mají oporu v konkrétních datech. Přehledová studie musí zahrnovat řadu výzkumů na dané téma, nikoli jen jeden.

Za přehledovou studii nelze dále považovat:

- text, který jen popisuje zaměření a obsah několika výzkumů na dané téma;

- text mající charakter souboru recenzí důležitých publikací na dané téma;

- soubor nestrukturovaných komentářru k publikacím, jež se zabývají daným tématem;

- text, který je posloupností doslovných citátů z několika publikací na dané téma.

Těmto textům zpravidla chybí zdůvodnění výběru zařazených publikací, důkladná analýza různých př́ístupů a získaných výsledků, chybí jim zhodnocení a pokus o syntézu. Přehledovou studií není ani polemický text, který bez obšírnější analýzy uvádí slabiny jedné badatelské školy či přímo útočí na určitý výzkumný směr, který zkoumá dané téma (Writing academic review, 2010).

V našich domácích pracích se objevuje ještě jeden typ textů, který rovněž nelze zařadit do žánru přehledových studií. Autor postupně představuje čte- 
nářům jednotlivé studie, které se věnovaly danému tématu, a to každou odděleně, samostatně. Řadí je jednoduše za sebou do dlouhé posloupnosti, aniž zdůvodňuje jejich výběr, aniž je navzájem porovnává, aniž je strukturuje do vyšších celků či souhrnně hodnotí. Nabízí tak čtenářům pouhý výčet informací o každém jednotlivém výzkumu. Obrazně řečeno jde o „tasemnici“, která může mít několik jednotek až desítek „článků“ a nepřináší novou kvalitu.

\section{$3 \quad$ Funkce přehledových studií}

V dostupné literatuře nalézáme různé výčty různých funkcí, které může přehledová studie a její zpracovávání plnit. Obvykle jde o nečleněný seznam funkcí, o pouhý výčet. My jsme zvolili odlišný přístup a rozdělili jsme běžně uváděné funkce do čtyř skupin (viz tab. 2 na s. 436-437).

Tab. 2 shrnula čtyři hlavní př́nosy přehledových studií: pro porozumění předkládané jedné výzkumné studii; pro odborné zrání mladého začínajícího autora přehledu; pro vývoj daného oboru; pro zkušeného badatele, který se přesouvá na nové výzkumné pole.

\section{Volba vhodného tématu pro přehledovou studii}

Volba tématu pro přehledovou studii bývá spoluurčována několika faktory: zájmem samotného autora o určitou výzkumnou oblast; vypsáním tématu kvalifikační práce akademickým pracovištěm, přičemž student obvykle vybírá z předem stanovených témat; zadáním konkrétního tématu školitelem nebo vedoucím pracovníkem instituce konkrétnímu jednotlivci; potřebou podat výzkumný grant na dané téma, jehož součástí je přehled současného stavu bádání; vypsáním tématu redakcí určitého časopisu; potřebami daného vědního oboru, který dospěl do takové vývojové fáze, že si potřebuje ujasnit současný stav poznání; snahou rozhodnout spory mezi zastánci různých koncepcí výzkumu v dané oblasti; potřebami praxe, jak nejlépe postupovat při řešení daného problému (jde o doporučení, jež jsou založena na důkazech (Mareš, 2009; Mareš \& Kebza, 2012).

V odborné literatuře (napr. Writing a psychology literature review, 2010) nalezneme některá doporučení, jak postupovat při výběru tématu, přesněji jeho obsahového zaměření: 


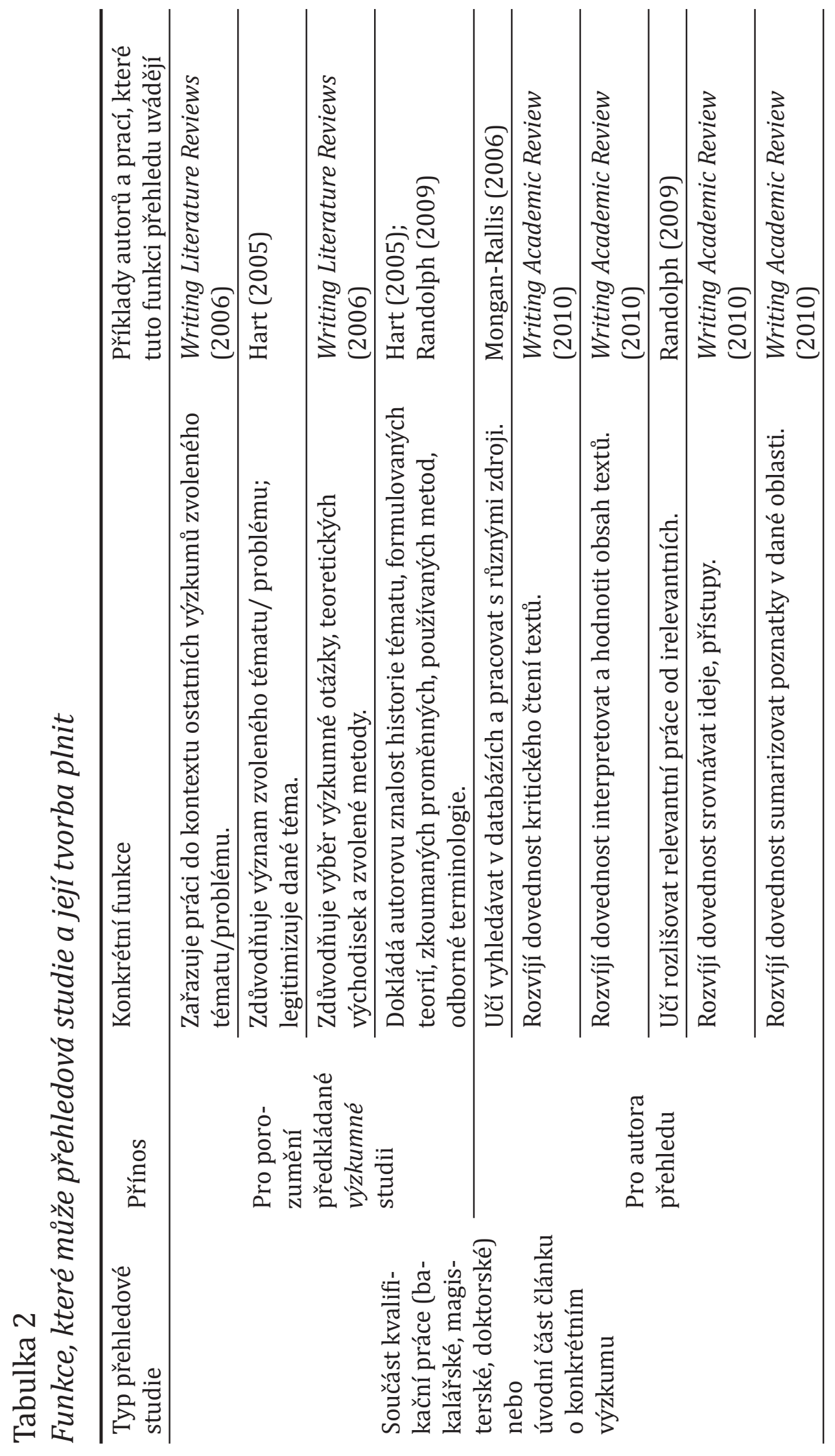




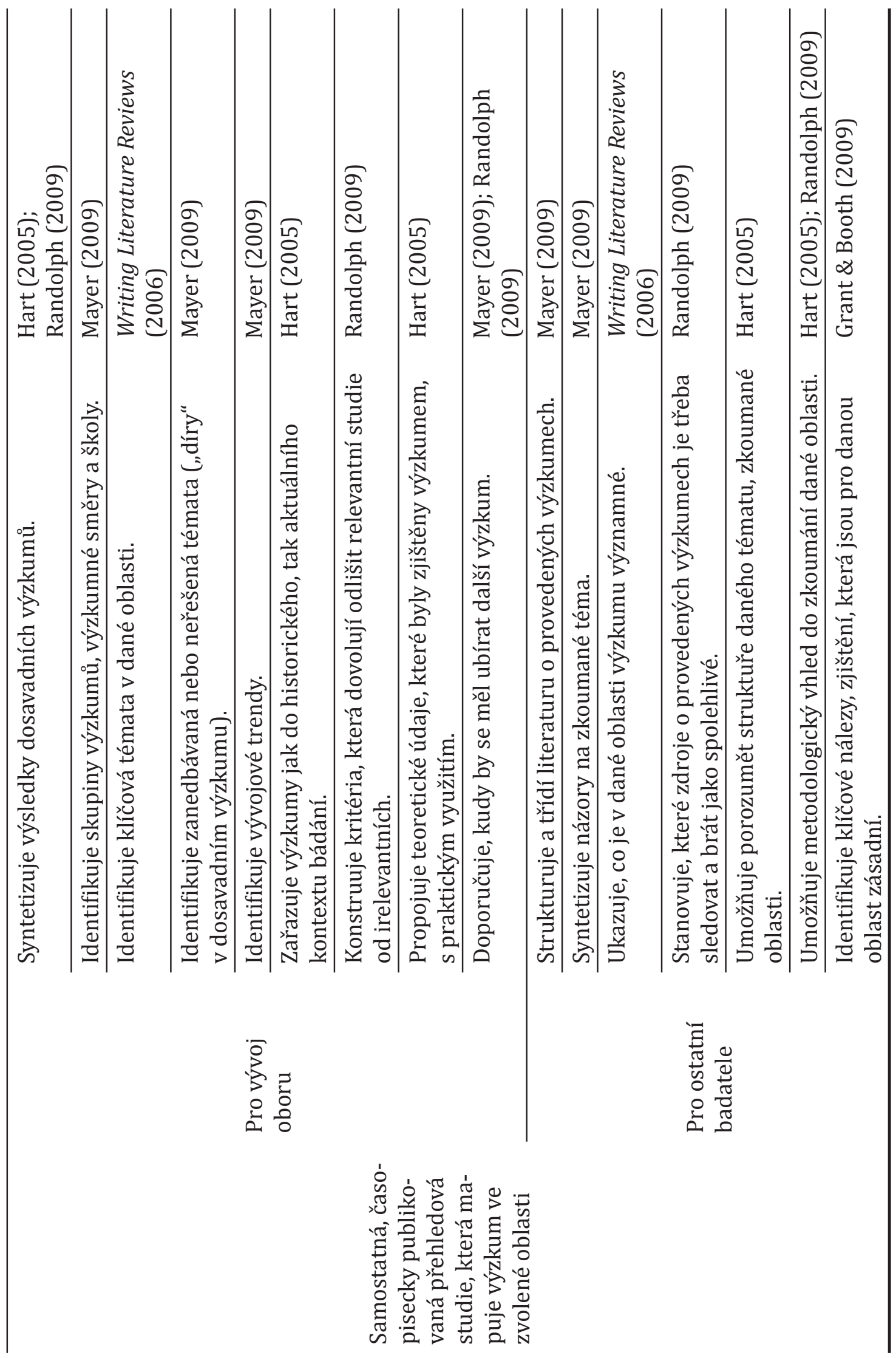


Vyberte si téma, které je v daném oboru aktuální, je středem vědeckého zájmu. Vyhýbejte se - pokud nepíšete historický přehled - tématům již uzavřeným či tématům, o nichž se ví, že jsou ve výzkumu „slepou uličkou“. To, co je nosné, „žhavé“, zjistíte ve špičkových domácích a zahraničních časopisech. Nelitujte, že téma, které vás ted' osobně zajímá, není těžištěm zájmu vědecké komunity. Uvědomte si, že zatím nemáte přehled o celé zkoumané problematice a váš momentální zájem o jedno téma (často vágně formulované) mohl být vyvolán nějakým okrajovým impulsem.

Vyberte si oblast bádání, která je relativně dobře vymezena a přesněji popsána. Literatura o ní vám nabídne několik hlavních směrů výzkumu, z nichž si můžete vybrat. Určitý směr výzkumu bývá charakterizován sérií publikací jednoho či dvou vůdčích badatelů anebo sérií publikací jednoho výzkumného týmu či vědecké školy. V rámci zvoleného směru výzkumu pak jistě naleznete téma, které zatím nebylo hlouběji zpracováno.

Volte si užší téma. Téma zpracovávaného přehledu závisí jednak na čase, který na zpracování máte, jednak na typu publikace, do níž je přehled určen (článek o jednom empirickém výzkumu, jehož úvodní částí má přehled být; kapitola v kvalifikační práci; samostatný přehledový článek v časopise). Užší téma dovoluje jít autorovi přehledu do hloubky. A právě zde se setkáváme s paradoxem přehledů: má-li autor vybrat a poté zpracovat užší téma, musí mít nadhled, celkový prehled o dané oblasti. Nejprve je tedy třeba se zorientovat $\mathrm{v}$ širší oblasti, abychom mohli důkladně zpracovat téma užší.

Pište o tom, co vás osobně zaujalo. Pokud se autor sám zajímá o určité téma, „žije“ svým tématem, pak vynaloží více úsilí při jeho př́ípravě i invence při psaní. Výsledný text bude pravděpodobně zajímavější i pro čtenáře. Druhý případ - kdy autor dostane nařízeno napsat o něčem, co ho vůbec nezajímá mívá obvykle opačné účinky (modifikovaně podle Writing a psychology literature review, 2010).

Nejde však jenom o samotné téma, tedy obsah přehledu. Další etapou je zvolit si typ přehledové studie, stanovit si, co je cílem přehledu, a tedy rozhodnout, na který typ otázek má přinést odpovědi. Má-li přehled integrovat výsledky dosavadního bádání, může být výzkumná otázka formulována např. takto: $C o$ zjistila dosavadní literatura o účinku intervence X na proměnné Y a Z? Je-li cílem kritická analýza dosud používaných výzkumných metod, může mít otázka tuto podobu: Které výzkumné metody se dosud používaly při zkoumání jevu X? 
Které metodologické slabiny mají tyto metody? Pokud je přehled zaměřen na vědecké teorie a jeho cílem je identifikovat jejich klíčové problémy, potom jsou legitimní otázky: Které klíčové teorie byly dosud navrženy pro vysvětlení jevu X? V čem spočívají jejich silné a $v$ čem slabé stránky? (modifikovaně podle Randolph, 2009)

\section{Doporučovaný postup při př́ípravě přehledové studie}

\subsection{Doporučovaný sled kroků}

Tvorbu přehledové studie můžeme rozdělit do sledu jednotlivých kroků, svébytných etap, které vedou autora až $\mathrm{k}$ výsledné podobě přehledu. Jedna z možných posloupností má tuto podobu (viz tab. 3 na s. 440).

\subsection{Rešerše odborné literatury}

Je nepravděpodobné, aby platil výrok některých začátečníků: tohle téma ještě nikdo nezkoumal ... Ve světové odborné literatuře vždy najdete publikace, které se daným tématem přímo zabývají anebo se mu obsahově velmi blíží. Je však třeba se k nim propracovat a seznámit se s nimi. Vyhledání vhodných publikací lze provést několika způsoby, ale nejobvyklejší jsou dva: zadat vyhledávání specialistům - knihovníkům ve velkých knihovnách, anebo si potřebnou literaturu vyhledat sám. Literární prameny se nevyhledávají jen v katalozích knihoven, nepůjčují se pouze k prezenčnímu nebo k domácímu studiu, ani jen prostřednictvím meziknihovní výpůjční služby.

V současné době jsou hlavním zdrojem potřebných pramenů různé mezinárodní elektronické databáze. Jsou to jednak obecně koncipované databáze (Web of Knowledge, Proquest, Ovid, EBSCO), které zahrnují většinu vědních oborů a shromažd'ují převážně anglicky psané publikace z USA, Kanady, Austrálie, Velké Británie apod. Dále jsou zájemcům k dispozici specializované databáze, např. pro pedagogiku (ERIC), pro psychologii (PsycInfo, PsycArticles), pro medicínu (Medline, PubMed) aj. Funguje též obecně koncipovaná databáze, která prioritně shromažd'uje publikace vzniklé v Evropě (Scopus). Zmiňme též veřejně př́stupnou databázi Scirus, která zastř̌ešuje většinu odborných databází a zachycuje též doktorské disertace a internetové publikace. Při vyhledávání potřebné literatury mohou být užitečné i běžné internetové vyhledavače typu Google. 


\section{Tabulka 3}

\section{Doporučený postup při psaní přehledové studie}

1. Zvolte pro svou přehledovou studii téma, které je vhodné svým obsahem i rozsahem (podrobnosti viz oddíl č. 4).

2. Zvolte vhodný typ přehledové studie (podrobnosti viz oddíly č. 1 a 2).

3. Proved'te rešerši odborné literatury na dané téma (podrobnosti viz oddíl 5.2). Jejím výsledkem bývá rozsáhlý soupis prací věnovaných empirickým výzkumům, metodologickým přístupům či vědeckým teoriím.

4. Analyzujte základní údaje o každé identifikované práci a snažte se zúžit prvotní výběr prací jen na relevantní studie.

5. Kriticky pročtěte, detailně analyzujte a popište každou studii ze zúženého výběru.

6. Zpracujte údaje o všech těchto prostudovaných studiích do podoby srovnávací tabulky (viz tabulky č. 5 až 7), příp. do podoby pojmové mapy.

7. S oporou o srovnávací tabulku identifikujte klíčové charakteristiky zvoleného tématu, které se vynořily z analyzovaného souboru studií.

8. Syntetizujte získané charakteristiky zvoleného tématu do větších celků.

9. Začněte sepisovat jednotlivé části přehledové studie o daném tématu.

10. Upravujte jednotlivé pracovní verze své přehledové studie tak dlouho, až vznikne koherentní text. Využijte možností konzultací, námětů a kritických připomínek kolegů, kolegyň i specialistů na dané téma.

Je však třeba dodat tři důležité poznámky. Mezinárodní databáze plnotextové odborné literatury jsou databázemi placenými, nejsou tedy př́stupny zájemcům odkudkoli, nýbrž jen z počítačů, které jsou napojeny na fakultní či univerzitní sít'. Jednotlivé fakulty i univerzity se zpravidla liší v tom, které databáze si zakoupily a v jakém rozsahu je provozují. Za druhé, pro vyhledání potřebných publikací na dané téma je nutné obsah tématu charakterizovat co nejpřesněji pomocí klíčových slov a logických operátorů. Tímto zadáním se řídí vyhledávací program. Za třetí, zájemce musí zadat také časové období, které ho zajímá; jazyk/jazyky, v nichž publikace vyšly; typ vyhledávaných publikací (např. články, přehledové studie, články v tisku, knihy, příspěvky v konferenčních sbornících, doktorské disertace, výzkumné zprávy atd.).

Pro prvotní orientaci ve zvoleném tématu je užitečné začít s vyhledáváním a studiem dosud publikovaných přehledových studií, aby zájemce o dané téma získal určitý nadhled. Metaforicky řečeno, aby se „postavil na ramena obrü“. Teprve pak se může pustit do studia mnoha dílčích výzkumných prací.

\subsection{Zúžení prvotního výběru prací na relevantní studie}

Výsledkem rešerše bývá soupis mnoha desítek, častěji několika stovek prací na dané téma. I při pečlivé formulaci vyhledávací strategie (klíčových slov 
spojených logickými operátory) se v soupisu vyhledaných citací objeví i práce, které nejsou pro daný účel relevantní. Prvotní výběr je tedy třeba zredukovat. Jedna ze zásad pro vytváření přehledové studie, která se v posledních letech ve světě prosazuje, zní: explicitně definujte kritéria, podle nichž jste publikace pro svoji přehledovou studii vybrali. Uved'me si zjednodušený př́íklad (tab. 4).

Tabulka 4

Př́klad definování kritérií pro výběr publikací pro přehledovou studii

\section{Kritéria pro zařazení:}

- databáze, v nichž se vyhledání uskuteční (výčet)

- jen práce z posledních X let (tj. od... do...)

- jen práce publikované v těchto jazycích: ...

- jen práce z obdobných sociokulturních podmínek

- jen práce založené na empirickém výzkumu

- jen práce založené na kvantitativním/kvalitativním/smíšeném př́stupu

- jen práce, $v$ nichž jsou přesně popsány použité postupy

- jen práce, které se týkají určitého stupně školy (mateřské, základní, střední, vysoké)

- jen práce, v nichž je přesně popsán zkoumaný soubor osob (a způsob jeho výběru) atd.

Kritéria pro vyřazení:

- negace předchozích hledisek

- jiné žánry, např. editorial, úvahové studie, dopisy redakci, recenze publikací, zprávy z konferencí

Pokud použijeme zvolená kritéria, rozsáhlý soubor prvotně vyhledaných publikací se podstatně zredukuje, jak ukazuje obr. 1 na s. 442.

Vývojový diagram, jehož fiktivní příklad je uveden na obrázku 1, se v zahraničí již používá $\mathrm{v}$ přehledových studiích při popisu toho, jaká strategie byla použita při výběru publikací pro daný přehled.

\subsection{Kritické pročtení, analýza a popis relevantních studií}

Poslední blok vývojového diagramu na obr. 1 zahrnuje důkladnou analýzu všech studií, které byly nakonec zařazeny do kategorie „práce relevantní pro dané téma".

Pokud mají být texty analyzovány a navzájem porovnávány, potřebujeme údaje, které jsou v nich obsaženy, vybrat a uspořádat podle jednotných hledisek. Jedním z nejvhodnějších postupů jsou srovnávací tabulky. Podívejme se na čtyři prŕklady (tab. 5 až 7 na s. 443-445). 


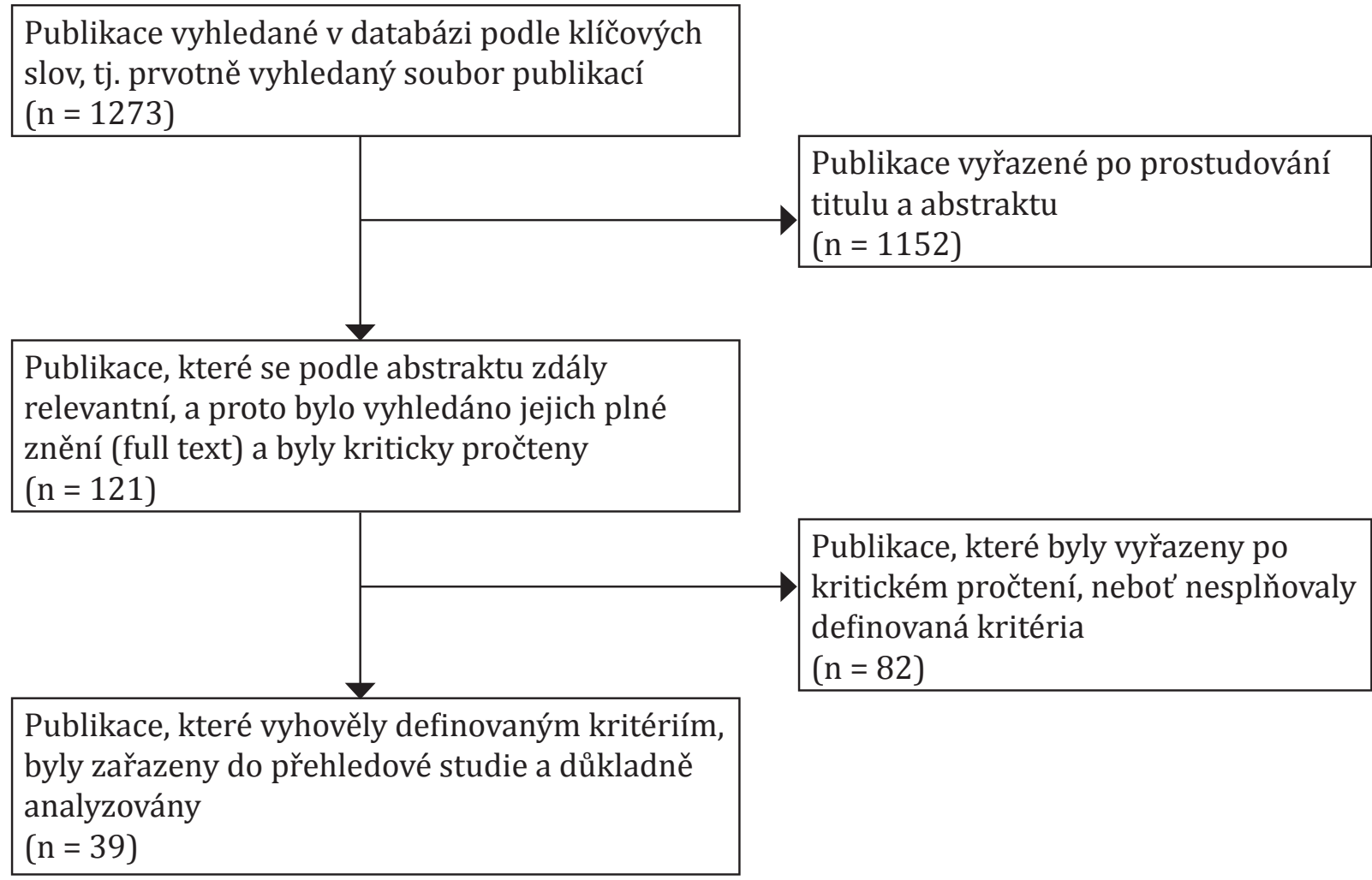

Obrázek 1. Modelový fiktivní př́klad postupu při redukování původně vyhledaného souboru publikací tak, aby zbyly jen relevantní publikace.

Tab. 5 na s. 443 ukazuje bohaté spektrum možných teoretických př́stupů, které se vyskytují při analýze a hodnocení teoretického základu posuzovaných výzkumů. Každý ze šesti uváděných přístupů se na zkoumanou realitu dívá $\mathrm{z}$ poněkud odlišného pohledu a tím dospívá i $\mathrm{k}$ poněkud odlišným výsledkům. Autor přehledové studie by měl u každého výzkumu, který do svého výběru zařadí, identifikovat i jeho teoretické zakotvení, aby skutečně srovnával srovnatelné.

Některé přehledové studie podávají čtenářům souhrnný pohled na diagnostické nástroje, které byly pro zjištování daného problému zatím vyvinuty a prakticky odzkoušeny. Nemůže však jít o pouhý výčet názvů těchto nástrojů, doplněný literárními odkazy na původní pramen. Čtenář musí dostat podrobnější údaje o jednotlivých nástrojích, aby se v nich mohl poučeně zorientovat. K tomu slouží tabulka, která charakterizuje diagnostické nástroje podle jednotných kritérií (viz tab. 7 na s. 445). 


\begin{tabular}{|c|c|c|}
\hline Teoretický př́istup & $\begin{array}{l}\text { Definice daného přístupu podle Snowman } \\
\text { et al. (2009) }\end{array}$ & $\begin{array}{l}\text { Práce zveřejněné v časopise } \\
\text { Contemporary Educational } \\
\text { Psychology, které z tohoto } \\
\text { přístupu vycházejí }{ }^{3}\end{array}$ \\
\hline behavioristický & $\begin{array}{l}\text { Teorie, které staví na podmiňování } \\
\text { a zpevňování lidského chování. }\end{array}$ & Morrison et al. (1995) \\
\hline kognitivní & $\begin{array}{l}\text { Teorie, které studují a vysvětlují poznávací } \\
\text { procesy člověka a jeho myšlení. }\end{array}$ & Ramsay \& Sperlik (2010) \\
\hline konstruktivistický & $\begin{array}{l}\text { Teorie, které studují a vysvětlují, jak } \\
\text { jednotlivci vytvářejí smysl dění, jak } \\
\text { konstruují svůj svébytný pohled na } \\
\text { skutečnost. }\end{array}$ & De Simone et al. (1999) \\
\hline informační & $\begin{array}{l}\text { Teorie, které studují a vysvětlují jednotlivé } \\
\text { etapy zpracování informací, např. vnímání, } \\
\text { kódování, zapamatování, vybavování. }\end{array}$ & Van Metter et al. (2006) \\
\hline metakognitivní & $\begin{array}{l}\text { Teorie, které studují a vysvětlují, co si } \\
\text { člověk myslí o svých vlastních procesech } \\
\text { myšlení a jak „poznání toho, jak poznává“, } \\
\text { mǔže zlepšit jeho učení. }\end{array}$ & Muis (2008) \\
\hline sociálně kognitivní & $\begin{array}{l}\text { Teorie, které studují a vysvětlují } \\
\text { observační učení a učení nápodobováním } \\
\text { vzorů; teorie, které zkoumají } \\
\text { interakci mezi chováním člověka, jeho } \\
\text { osobnostními zvláštnostmi a sociálním } \\
\text { prostředím. }\end{array}$ & Ciani et al. (2010) \\
\hline
\end{tabular}

Pozn. Upraveno podle Mitchell a McConnell (2013 s. 138).

Tabulka věnovaná charakteristikám diagnostických nástrojů může být pochopitelně i mnohem podrobnější. Mưže být rozšiřrena o další hlediska, např. o charakteristiku teoretického modelu, z něhož nástroj vychází; doporučený věk respondentů; vzorek osob, s nímž uváděný výzkum pracoval (počet osob, věk, pohlaví); o bližší charakteristiku vzorku osob (způsob výběru, etnické složení,sociálnísložení); validitu (např.validitasouběžná, konstruktováapod.).

Jakmile máme připraveny různé typy podkladů (včetně srovnávacích tabulek), můžeme začít se sepisováním přehledové studie.

3 Úplné údaje o těchto pracích naleznou zájemci v citované publikaci Mitchell a McConnell (2012). 


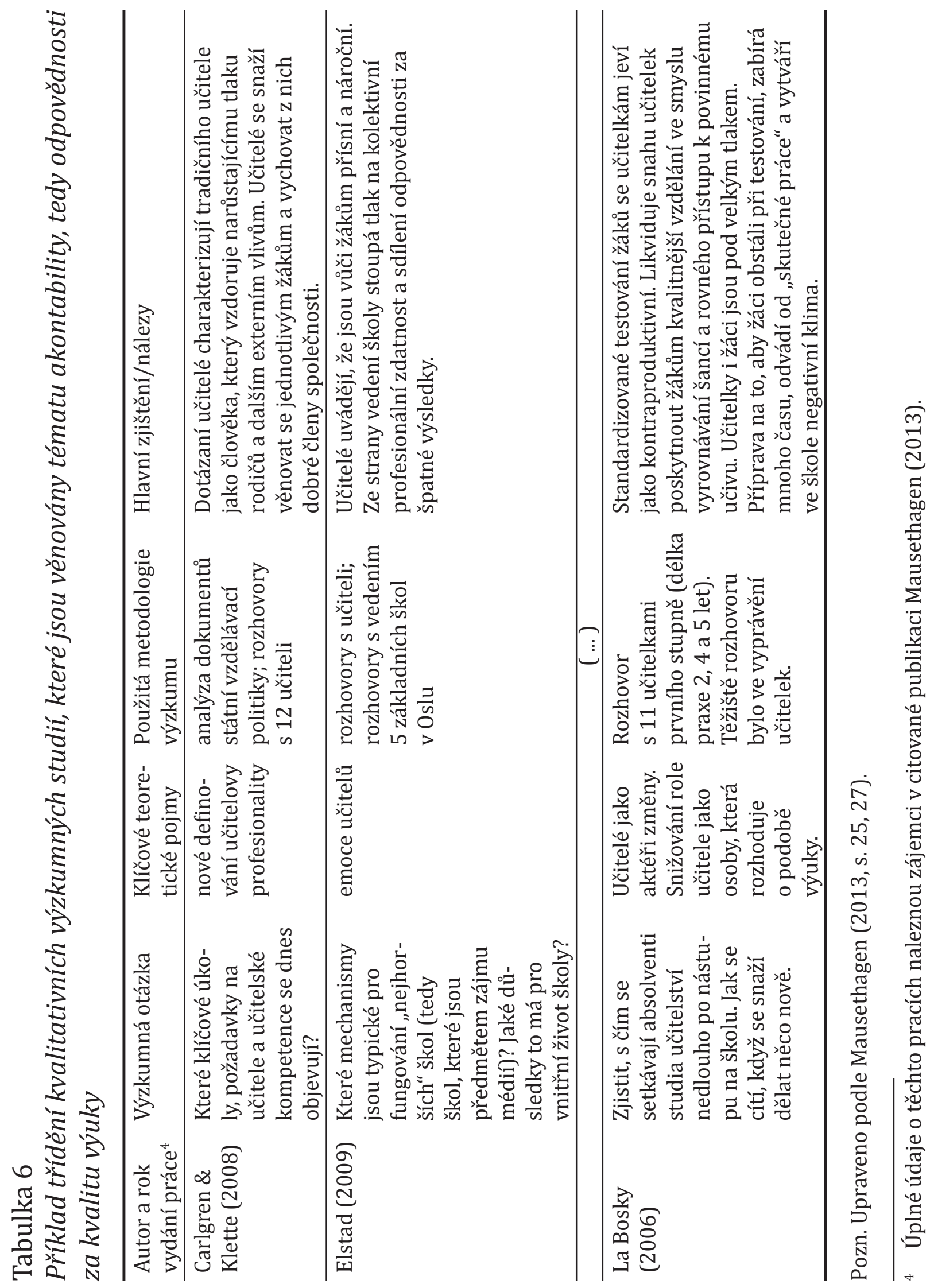




\section{Tabulka 7}

Př́klad tř́dění diagnostických nástrojů, které zjištujují psychosociální klima školní tř́ldy

\begin{tabular}{|c|c|c|c|c|c|}
\hline $\begin{array}{l}\text { Název nástroje } \\
\text { a autor }\end{array}$ & $\begin{array}{l}\text { Počet } \\
\text { položek }\end{array}$ & $\begin{array}{l}\text { Způsob } \\
\text { odpovídání }\end{array}$ & Obsahová struktura & Reliabilita & Komentářr \\
\hline $\begin{array}{l}\text { CES - Classroom } \\
\text { environment scale } \\
\text { (Moose \& Trickett, } \\
\text { 1974; Fraser \& } \\
\text { Fisher, 1983) }\end{array}$ & 23 & $\begin{array}{l}\text { dichotomická } \\
\text { škála: ano-ne }\end{array}$ & $\begin{array}{l}6 \text { proměnných: } \\
\text { (1) učitelova pomoc } \\
\text { žákům, (2) orientace } \\
\text { žáků na úkoly, } \\
\text { (3) vztahy mezi žáky } \\
\text { ve škole, (4) zájem } \\
\text { o průběh výuky, } \\
\text { (5) klid a pořádek } \\
\text { ve třídě, (6) jasnost } \\
\text { pravidel }\end{array}$ & $\begin{array}{l}\text { Cronba- } \\
\text { chovo alfa } \\
0,59-0,74\end{array}$ & $\begin{array}{l}\text { existuje } \\
\text { standar- } \\
\text { dizovaná } \\
\text { česká } \\
\text { verze } \\
\text { (Mareš, } \\
\text { 1998) }\end{array}$ \\
\hline $\begin{array}{l}\text { MCI-SF My class } \\
\text { inventory - Short } \\
\text { form (Fraser \& } \\
\text { Fisher, 1986) }\end{array}$ & 25 & $\begin{array}{l}\text { dichotomická } \\
\text { škála: ano-ne }\end{array}$ & $\begin{array}{l}\text { 5 proměnných: } \\
\text { 1. spokojenost, } \\
\text { 2. soudržnost, } \\
\text { 3. třenice, } \\
\text { 4. soutěživost. } \\
\text { 5. obtížnost úkolů }\end{array}$ & $\begin{array}{l}\text { Cronba- } \\
\text { chovo alfa } \\
0,73-0,88\end{array}$ & $\begin{array}{l}\text { existuje } \\
\text { česká } \\
\text { verze, ale } \\
\text { nebyla } \\
\text { zatím } \\
\text { standardi- } \\
\text { zována } \\
\text { (Lašek } \\
\text { \& Mareš, } \\
\text { 1991) }\end{array}$ \\
\hline $\begin{array}{l}\text { MCEI - Multicultu- } \\
\text { ral classroom envi- } \\
\text { ronment instrument } \\
\text { (Carroll, 2006) }\end{array}$ & 64 & $\begin{array}{l}\text { pětistupňová } \\
\text { škála }\end{array}$ & $\begin{array}{l}9 \text { proměnných: } \\
\text { (1) spolupráce, } \\
\text { (2) soutěžení, } \\
\text { (3) učitelova } \\
\text { autorita, (4) učite- } \\
\text { lova pomoc } \\
\text { žákům, (5) shoda, } \\
\text { soulad, (6) rozdíly, } \\
\text { (7) učitelův } \\
\text { individuální } \\
\text { přístup k žákům, } \\
\text { (8) učitelův direk- } \\
\text { tivní přístup } \\
\text { k žákům, (9) rovnost } \\
\text { pohlaví }\end{array}$ & $\begin{array}{l}\text { Cronba- } \\
\text { chovo alfa } \\
0,63-0,87\end{array}$ & \\
\hline
\end{tabular}

Pozn. Převzato z Mareš (2013, s. 597).

5 Úplné údaje o těchto pracích naleznou zájemci v citované publikaci Mareše (2013).

6 Úplné údaje o zmiňovaných pracích naleznou zájemci v citované publikaci Mareše (2013). 


\section{Doporučovaný postup při sepisování přehledové studie}

Návodů, jak psát přehledové studie bylo už publikováno mnoho. Pomáhají autorovi, aby nezapomněl na nic podstatného, ale neudělají práci za něj. Psaní přehledu je řemeslo a je třeba se mu naučit. První pokusy bývají zdlouhavé, pracné a nevyznívají tak dobře, jak si začínající autor přeje. Někteří odborníci tvrdí, že psaní přehledů má ještě cosi navíc. Vyzrálí autoři totiž vnášejí do přehledu tvořivé prvky a posouvají sepisování přehledových studií do kategorie umění psát přehledy (Short, 2009).

V dalším výkladu se přidržíme těch doporučení, která uvádí MonganRallis (2006) a především Galvan (2006). Jejich rady uvedeme s určitými modifikacemi.

\subsection{Syntetizování literárních poznatků}

- Uvědomte si účel svého přehledu a typ přehledové studie, který jste si zvolili.

- Projděte si klíčové pojmy, s nimiž budete pracovat, a ujistěte se, že jim rozumíte; že dokážete při výkladu odlišit, co pod nimi rozumějí jednotliví autoři a v čem se jejich názory liší.

- Restrukturujte své poznámky, protože přehledová studie není soupisem anotací vybraných výzkumných studií. Připravené poznámky musíte podř́́dit logice uceleného výkladu.

- Vypracujte si osnovu celé přehledové studie a uvnitř každého oddílu promyslete sled př́kladů a argumentů.

- Uvnitř každého oddílu identifikujte, v čem se analyzované výzkumné studie navzájem shodují a v čem se naopak liší.

- Uvnitř každého oddílu identifikujte, která témata zřejmě nejsou dost prozkoumána či se nezkoumají vůbec a bylo by vhodné, aby se další výzkum vydal těmito směry.

- Rozvrhněte si, jak budete čtenářům představovat teorie, které vysvětlují dané téma (zvolte hlediska analýzy, stanovte vhodné pořadí teorií, shrnutí nálezů apod.). 
- Diskutujte, nakolik jsou jednotlivé výzkumné studie zakotveny v teoriích a nakolik je obohacují.

- Rozvrhněte si, jak budete sumarizovat nejdůležitější výsledky své analýzy relevantních studií.

\subsection{Postup při psaní přehledu}

- Identifikujte hlavní problémové oblasti daného tématu; vyhýbejte se však povšechným, nedoloženým tvrzením.

- Na začátku výkladu uved'te, proč považujete téma, které jste si vybrali pro přehledovou studii, za důležité.

- Pokud argumentujete aktuálností zvoleného tématu, uved'te, $v$ jakém časovém rámci tento argument platí.

- Rozlišujte mezi nálezy, které jsou doloženy empirickými výzkumy a tvrzeními, která se běžně používají bez průkazných argumentů, bez dokladů, že odpovídají reálné situaci ${ }^{7}$. Uvědomte si, že i jednotlivé - byt' pravdivé případy, tedy kazuistiky - nevypovídají o celkové situaci.

- Specifikujte, proč jsou některé publikace ve vašem přehledu důležitější než jiné.

- Pokud citujete klasické práce nebo klíčové výzkumy, podívejte se do nich a nepřebírejte mechanicky názory jiných lidí. Zjistěte si také, zda mezitím nedošlo k zopakování takového výzkumu a pokud ano, uved'te, s jakými výsledky.

- Pokud jste $v$ literatuře našli jiné přehledové studie na téma, které zpracováváte, zmiňte to a diskutujte, $\mathrm{v}$ čem na tyto přehledové studie navazujete a v čem je originální přínos vaší práce.

- Pokud jste se k některé důležité výzkumné studii nedostali, přiznejte to a vysvětlete, proč byla pro vás tato práce nedostupná.

- Pokud zjistíte, že dosavadní výzkumy jsou nekonzistentní, zatímní výsledky si odporují anebo široce variují, proberte práce s podobnými výsledky nejprve odděleně a teprve potom diskutujte možné důvody, proč se hlavní skupiny výzkumů rozcházejí.

7 Připomeňme novinářská tvrzení typu: naše škola nutí děti biflovat; není třeba si nic pamatovat, většinu poznatků lze přece najít na internetu atd. 


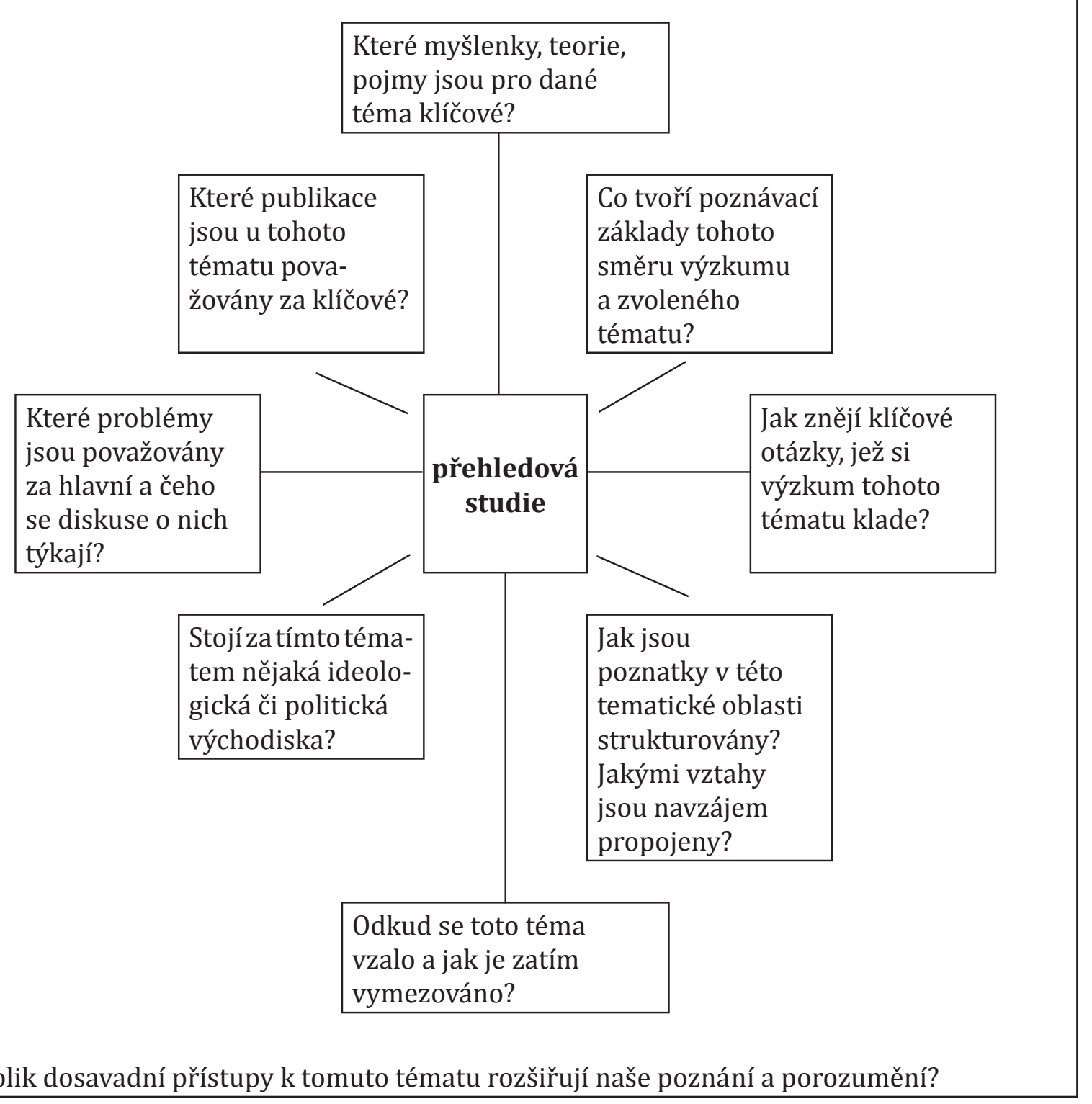

Nakolik dosavadní přístupy k tomuto tématu rozšiřují naše poznání a porozumění?

Obrázek 2. Otázky, na něž může přehledová studie přinést odpovědi. Převzato z Hart (2005, s. 14).

- Stává se, že napsaný text je relativně dlouhý. Pak ho musíte zredukovat na požadovaný rozsah. Člověku to bývá líto, ale zase se tím naučí rozlišovat, které části textu jsou skutečně důležité a které může klidně oželet, aniž to uškodí celkovému vyznění přehledu.

- Cílem přehledové studie je analyzovat, hodnotit a integrovat poznatky, které přinesly relevantní výzkumné studie, nikoli ustrnout na popisu 
dosavadního snažení. Musíte čtenářům sdělit své stanovisko, nejen referovat o názorech druhých.

- Přehledové studie nebývají krátké, a proto je třeba text rozčlenit do vhodných tematických celků, do samostatných oddílů, které musí mít své mezititulky. Nezapomínejte rovněž, že přechody mezi oddíly musí být logické a stylisticky plynulé.

Právě uvedená doporučení se týkají dílčích aspektů, které musí mít autor na mysli, když píše přehledovou studii. Pokud bychom měli shrnout to nejdůležitější, co by si měl autor přehledu ujasnit, můžeme to přiblížit schématem na obr. 2, s. 448.

\section{Typické chyby při psaní přehledové studie}

Až dosud jsme mluvili o tom, jak správně postupovat, aby výsledná přehledová studie byla co nejkvalitnější. Nyní se zastavíme u komplementárního problému: čeho se vyvarovat, aby výsledná studie byla co nejkvalitnější. Dunkin (1996) se pokusil ve svém kritickém přehledu upozornit na nejzávažnější chyby, jichž se autoři přehledových studií dopouštějí. Základní chyby shrneme do několika bodů; zájemce o detailnější poučení a konkrétní příklady odkazujeme na originální text:

- Při výběru publikací o daném tématu se někdy uplatňuje skrytá selektivita. Nejde jen o selektivitu na základě jazyka, v němž byla výzkumná studie publikována. Někdy autor neuvede kritéria, podle nichž relevantní práce vybíral. Jindy je sice uvede, ale ne vždy se jimi řídí (nezařadí publikace, které by se v přehledu objevit měly; preferuje určitý směr výzkumu aj.). Tím vzniká pokřivený obraz o stavu bádání daného tématu. Přehled nereprezentuje všechny relevantní názory a výzkumné nálezy, i když se tak tváŕí.

- Autor dostatečně nerozlišuje kvalitu vyhledaných publikací. Do užšího výběru se tak dostanou i publikace, které nesplňují základní metodologické požadavky. Např. v přehledu se objeví příspěvky z konferencí, které ještě neprošly recenzním řízením $\mathrm{v}$ odborném časopise; jsou jen předběžným, nikoli dopracovaným sdělením. Autor - to už dodáváme my - si někdy neuvědomuje výrazné rozdíly $\mathrm{v}$ úrovni časopisů, odkud články přebírá. Jinou váhu mají údaje publikované v časopisech s náročným recenzním řízením, jinou údaje publikované v lokálních časopisech. Další problém 
u nás představují některé kvalifikační práce, jejichž autoři nekriticky přebírají texty z problematických internetových zdrojů.

- Autor přehledu důsledně nekontroluje, zda publikované výzkumy mají všechny náležitosti, které jsou potřebné pro posouzení jejich kvality (typ výzkumného projektu; úplný popis zkoumaného souboru; definování způsobu, jímž byl soubor vybrán; důkladný popis použité metody; charakterizování kontextu výzkumu atd.). Důsledkem bývá nevhodné zařazení dané práce do určitého typu publikací anebo srovnávání problematických výsledků takové publikace se spolehlivými výsledky jiných výzkumů.

- Započítávání téhož výzkumu vícekrát. Výsledky, které byly získány v rámci rozsáhlých výzkumných projektů, bývají výzkumným týmem někdy publikovány po částech $\mathrm{v}$ různých časopisech. Může se tedy stát, že málo pečlivý autor přehledu si neuvědomí, že nejde o jiné výzkumy, ale jen o jiné aspekty stále stejného většího výzkumu. Jinak řečeno: jednotkou analýzy by měl být ,jeden empirický výzkum“, nikoli „publikační výstupy“, které referují o jeho výsledcích a jejich počet.

- Nerozpoznání chyb v autorových závěrech. Vyskytnou se autoři článků o výzkumu, kteří při formulaci závěrů své výzkumné studie jdou nad úroveň zobecnění, kterou připouští jejich výzkumný projekt; jejich tvrzení jsou nadměrně zobecňující. Jsou i autoři, kteří do závěrů své práce vybírají ty výsledky, které podporují jejich hypotézy a nevěnují dostatečnou pozornost těm výsledkům, které naznačují jinou možnou interpretaci.

- Potlačení vědeckých názorů či směrů výzkumu, s nimiž autor přehledu nesouhlasí. Bývá to $v$ př́ípadech, kdy do tvorby přehledové studie vstupují osobní animozity mezi badatelskými osobnostmi či mezi rozdílnými vědeckými školami. Jindy se při tvorbě přehledu zase odsunují do pozadí ty publikace, které přinášejí odlišné výsledky, než by potřeboval autor přehledu pro celkové vyznění svého přehledu.

- Kumulování chyb. Chyby (byt’ drobné) v jednotlivých etapách práce na přehledu se obvykle hromadí a ve svém důsledku mohou znehodnotit celkovou kvalitu přehledové studie. Př́kladem může být přehled diagnostických nástrojů, u nichž v tabulce není uvedeno, zda už jsou rutinně použitelné, anebo teprve ve stádiu pokusného ověřování. Oba případy mohou potenciálního uživatele inspirovat, ale ve druhém případě musí být velmi obezřetný při interpretování uváděných výsledků. 


\section{Závěr}

Každý rok pregraduální studenti vysokých škol píší své kvalifikační práce, každý rok doktorandi píší své disertace, každý rok vědečtí pracovníci podávají výzkumné granty. Vždy je v těchto pracích zapotřebí shrnout současný stav poznání ve zvolené oblasti bádání. Vznikají tak přehledové studie různého rozsahu a různé kvality, nebot' jejich autoři leckdy tápou, jak je vlastně napsat.

Přehledová studie sama totiž představuje - jak jsme připomněli v úvodu specifický literární žánr a ten má svá pravidla. V zahraničí jsou problémy s psaním přehledových studií relativně dobře zmapovány, publikují se doporučené postupy a zahraniční vysoké školy pro své studenty pořádají specifické, prakticky zaměřené kursy. Nejde v nich jen o sdělování potřebných informacía poučování-jak se u nás leckde děje v rámci předmětů typu Př́prava bakalářské práce, Diplomový seminár apod. Na zahraničních univerzitách se studenti ve specifických kursech učí přemýšlet nad jednotlivými etapami psaní přehledu a procvičují si také potřebné „řemeslné dovednosti“.

Máme-li se jim v tomto žánru přiblížit, je třeba, abychom se mohli opř́it o určitá (byt' rámcová) doporučení. S oporou o odbornou literaturu jsme ukázali, kolik různých podob může přehledová studie nabývat, a popsali jsme specifika jednotlivých typů. Pro zájemce jsme shrnuli a utř́ídili základní funkce, které přehledové studie mohou plnit. Upozornili jsme na obtíže, které jsou spojeny s vhodnou volbou tématu přehledové studie. Charakterizovali jsme postupy, jež autorům usnadňují přípravu pracovních podkladů pro přehledovou studii. Nabídli jsme i soupis základních doporučení, jimiž se autor může řídit při vlastním sepisování přehledové studie. Celý výklad byl konkretizován řadou ilustrativních př́kladů, které mohou uživatele inspirovat k tvořivému použití. Vzorové ukázky toho, jak se píší přehledové studie, jsou články, které vycházejí ve specializovaném časopise Review of Educational Research (http://rer.sagepub.com). Vychází od r. 1931 a je špičkou mezi pedagogickými časopisy, které vycházejí v angličtině.

Náš přehled nemohl obsáhnout celou problematiku. Ponechal stranou důležité (a přitom zajímavé) otázky, např jak tvořit přehledy těch výzkumů, v nichž byla použita smíšená metodologie (Heyvaert et al., 2013)? V př́ípadě, že je na totéž téma $\mathrm{k}$ dispozici více přehledových studií než jedna, $\mathrm{k}$ jakým výsledkům dospějeme, když je začneme porovnávat (Woodman et al., 2012)? Která hlediska máme zvolit, abychom zodpovědně posoudili, zda je daná přehledová studie kvalitní, nebo ne (Boote \& Beile, 2005)? 
Nazávěr připojujemejen dvěpřání. Aby (1) tento textalespoň dílčím způsobem přispěl $\mathrm{k}$ postupnému zlepšování úrovně přehledových textů $\mathrm{v}$ domácích kvalifikačních pracích i v časopiseckých článcích, (2) se v dohledné době tento text dočkal pokračování. Vždyt' tvorba dobrého přehledu kultivuje jak autora, tak čtenáře.

\section{Literatura}

Bem, D. J. (1995). Writing a review article for Psychological Bulletin. Psychological Bulletin, 118(2), 172-177.

Boote. D. N., \& Beile, P. (2005). Scholars before researchers: On the centrality of dissertation literature review in research preparation. Educational Researcher, 34(6), 3-15.

Cooper, H. M. (1988). Organizing knowledge synthesis: A taxonomy of literature reviews. Knowledge in Society, 1(1), 104-126.

Crowe, L. M., Beauchamp, M. H., \& Catroppa, C. et al. (2011). Social function assessment tools for children and adolescents: A systematic review from 1988-2010. Clinical Psychology Review, 31(5), 767-785.

Dunkin, M. J. (1996). Types of errors in synthesizing research in education. Review of Educational Research, 66(2), 87-97.

Eco, U. (1997). Jak napsat diplomovou práci. Olomouc: Votobia.

Galvan, J. (2006). Writing literature reviews: A guide for student of the behavioral sciences. Glendale: Pyrczak Publishing.

Geršlová, J. (2009). Vádemékum vědecké a odborné práce. Praha: Professional Publishing.

Grant, M. J., \& Booth, A. A. (2009). Typology of reviews: An analysis of 14 review types and associated methodologies. Health Information and Libraries Journal, 26(1), 91-108.

Hart, C. (2005). Doing a literature review: Releasing the social science research imagination. London: Sage.

Hendl, J. (2004). Přehled statistických metod zpracování dat. Praha: Portál.

Heyvaert, M., Maes, B., \& Onghena, P. (2013). Mixed methods research synthesis: Definition, framework, and potential. Quality and Quantity, 47(2), 659-676.

Khangura, S., Konnyu, K., \& Cushman, R. et al. (2012). Evidence summaries: The evolution of rapid review approach. Systematic Reviews, 1(10), 1-13. Dostupné z http://www. systematicreviewsjournal.com/content/1/1/10

Writing academic review. (2010). Peterbourough: Trent University, Academic Skills Centre.

Writing a psychology literature review. (2010). Seattle: University of Washington, Psychology Writing Center. Dostupné z http://www.psych.uw.edu/psych.php\#p=339.

Writing literature reviews. (2006). Melbourne: Monash University. Dostupné z http://www. monash.edu.au/lls/llonline/writing/general/lit-reviews/print-section.doc

Mareš, J. (1995). Jak připravit přehledovou studii (power-pointová prezentace). Hradec Králové: Lékařská fakulta UK.

Mareš, J. (2009). Edukace založená na důkazech: inspirace pro pedagogický výzkum i školní praxi. Pedagogika, 59(3), 232-258.

Mareš, J. (2013). Pedagogická psychologie. Praha: Portál. 
Mareš, J., \& Kebza, V. (2012). Psychologie založená na důkazech. Československá psychologie, 56(2), 178-193.

Mausethagen, S. A (2013). Research review of the impact of accountability policies on teachers' workplace relations. Educational Research Review, 9(1), 16-33.

Mayer, P. (2009). Guidelines for writing a review article. Zurich-Basel: Plant Science Center. Dostupné z http://www.plantscience.ethz.ch/education/Masters/courses/Scientific_Writing

Mitchell, A. W., \& McConnell, R. (2012). A historical review of Contemporary Educational Psychology from 1995 to 2010. Contemporary Educational Psychology, 37(2), 136-147.

Moher, D., Tetzlaff, J., Tricco, \& A.C. et al. (2007). Epidemiology and reporting characteristics of systematic reviews. PLOS Medicine, 4(3), 447-455.

Mongan-Rallis, H. (2006). Guidelines for writing a literature review. Duluth: University of Minnesota.Dostupnéz http://www.duluth.umn.edu/ hrallis/guides/researching/litreview.html

Randolph, J. J. (2009). A guide to writing the dissertation literature review. Practical Assessment, Research and Evaluation, 14(13), 1-13. Dostupné $\mathrm{z}$ http://pareonline.net/getvn. asp? $=14 \& \mathrm{n}=13$.

Ridley, D. (2012). The literature review - a step-by-step guide for students. London: Sage.

Short, S. (2009). The art of writing a review article. Journal of Management, 35(6), 1312-1317.

Sipe, T. A., \& Curlette, W. L. (1997). A meta-synthesis of factors related to educational achievement: A methodological approach to summarizing and synthesizing meta-analyses. International Journal of Educational Research, 25(7), 583-698.

Spousta, V. (2000). Vádemékum autora odborné a vědecké práce. Brno: Pedagogická fakulta MU.

Whittemore, R., \& Knafl, K. (2005). The integrative review: Updated methodology. Journal of Advanced Nursing, 52(5), 546-553.

Woodman, J., Thomas, J., \& Dickson, K. (2012). How explicable are differences between reviews that appear to address a similar research question? A review of reviews of physical activity interventions. Systematic Reviews, 1(37), 1-16. Dostupné z http://www. systematicreviewsjournal.com/content/1/1/37

\section{Autor}

Prof. PhDr. Jiřri Mareš, CSc., Univerzita Karlova v Praze, Lékařská fakulta v Hradci Králové, Šimkova 870, 50038 Hradec Králové; e-mail: mares@lfhk.cuni.cz

\section{Reviews: Their typology, functions and how to write them}

Abstract: The study informs the reader about how to write a quality review, which would summarize the current knowledge of the selected research topic. The aim of this study is to present a typology of review studies, to characterize various functions performed by different types of review studies; to show how to proceed in the selection of topics, at the preparation of supporting documents, and at the actual writing a review. The first part presents 11 types of review studies, both the generally 
known and the less known ones. The second part is a brief overview of the genres that do not belong to the category of review studies. The third part characterizes different functions that are fulfilled by the reviews (the review studies may facilitate understanding of the presented research, they are beneficial to the study's author, to the development of the field or to other researchers). The fourth section of the text looks closer at the problems faced by the author when choosing the topic for the review study, and offers possible solutions. The fifth part summarizes the procedures for preparation of documents for a review study (literature research, reduction of the initial selected works, critical reading, text analysis, creation of review tables). The sixth section provides advice on how to proceed in the actual writing a review. Where appropriate, in addition to recommendations on how to proceed, typical mistakes are mentioned that should be avoided by the author. In developed countries, there are three types of materials teaching students and young scientists how to write a review study. These guidelines can be found on the University website (usually within so called Writing Centres) or are available as journal articles on this topic or there are more comprehensive guides. So far, there has not been such a set of guidelines available in the Czech Republic. The present overview tries to fill this gap. Apart from general advice and guidelines, it is completed with some practical examples.

Keywords: review, literature review, critical review, writing, guidelines

\section{Rok 2013 je mezinárodním rokem statistiky}

Cílem celosvětové kampaně Mezinárodní rok statistiky (International Year of Statistics) je zvýšit povědomí veřejnosti o vlivu statistiky na prakticky všechny oblasti života společnosti. V této souvislosti odkazujeme na užitečné učebnice, které mají (nejen) čeští pedagogové v současnosti k dispozici:

- Hendl, J. (2012). Přehled statistických metod: analýza a metaanalýza dat. Praha: Portál.

- Meloun, M., \& Militký, J. (2012). Interaktivní statistická analýza dat. Praha: Karolinum.

- Meloun, M., \& Militký, J. (2013). Kompendium statistického zpracování dat. Praha: Karolinum.

Základní informace o Mezinárodním roku statistiky najdete na internetových stránkách www.statistics2013.org. 